\title{
Effectiveness of mid-infrared spectroscopy for the prediction of detailed protein composition and contents of protein genetic variants of individual milk of Simmental cows
}

\author{
V. Bonfatti, G. Di Martino, and P. Carnier \\ Department of Animal Science, University of Padova, viale dell'Università 16, 35020, Legnaro, Padova, Italy
}

\begin{abstract}
Mid-infrared (MIR) spectroscopy was used to predict the detailed protein composition of 1,517 milk samples of Simmental cows. Contents of milk protein fractions and genetic variants were quantified by reversedphase HPLC. The most accurate predictions were those obtained for total protein, casein $(\mathrm{CN}), \alpha_{\mathrm{S} 1}-\mathrm{CN}$, $\beta$-lactoglobulin (LG), glycosylated $\kappa-\mathrm{CN}$, and whey protein content, which exhibited coefficients of determination between predicted and measured values in cross-validation (1-VR) ranging from 0.61 to 0.78 . Less favorable were results for $\beta-\mathrm{CN}(1-\mathrm{VR}=0.53), \alpha_{\mathrm{S}^{2}} \mathrm{CN}$, and $\kappa-\mathrm{CN}(1-\mathrm{VR}=0.49)$. Neither the content of $\alpha-\mathrm{LA}$ nor that of $\gamma-\mathrm{CN}$ was accurately predicted by MIR. Predicting the content of the most common milk protein genetic variants $\left(\kappa-\mathrm{CN} \mathrm{A}\right.$ and $\mathrm{B} ; \beta-\mathrm{CN} \mathrm{A}^{1}, \mathrm{~A}^{2}$, and $\mathrm{B}$; and $\beta$-LG A and $\mathrm{B})$ was unfeasible $(1-\mathrm{VR}<0.15$ for the content of $\kappa-\mathrm{CN}$ genetic variants and $1-\mathrm{VR}<0.01$ for the content of $\beta-\mathrm{CN}$ variants). The best predictions were obtained for $\beta$-LG A and $\beta$-LG B contents (1-VR of 0.60 and 0.44 , respectively). Results indicated that MIR is not applicable for predicting individual milk protein composition with high accuracy. However, MIR spectroscopy predictions may play a role as indicator traits in selective breeding to enhance milk protein composition. The genetic correlation between MIR spectroscopy predictions and measures of milk protein composition needs to be investigated, as it affects the suitability of MIR spectroscopy predictions as indicator traits in selective breeding.
\end{abstract}

Key words: mid-infrared spectroscopy, protein fraction, genetic variant, milk

\section{INTRODUCTION}

In recent years, milk protein composition (MPC) has gained an increased interest and studies have been

Received March 29, 2011.

Accepted September 5, 2011.

${ }^{1}$ Corresponding author: valentina.bonfatti@unipd.it carried out to assess variation of milk protein fraction contents (Heck et al., 2008), to investigate the effects of milk protein polymorphisms on MPC (Heck et al., 2009; Bonfatti et al., 2010b) and of MPC on the cheese-making properties of milk (Wedholm et al., 2006; Bonfatti et al., 2011). As associations between increased $\mathrm{k}-\mathrm{CN}$ content and decreased rennet coagulation time, enhanced curd firmness (Wedholm et al., 2006; Jõudu et al., 2008; Bonfatti et al., 2010a), and increased cheese yield (Wedholm et al., 2006) have been reported, interest in the cheese manufacturing industry for information on detailed MPC has increased.

Additive genetic variation of MPC is large enough (Schopen et al., 2009) to be exploited in breeding programs to enhance the suitability of bovine milk for cheese making or for the production of specific milk products. However, such programs require the availability of measurements of individual MPC on a large scale.

Large-scale studies on MPC are limited by difficulties related to chemical measurement of MPC. Assessment of MPC has been typically performed using electrophoretic techniques and isoelectric focusing, and, more recently, HPLC (Bonfatti et al., 2008) and capillary electrophoresis (Heck et al., 2008). In particular, good separations, high resolutions, and good reproducibility have been obtained when quantification of major bovine milk protein fractions and of the most common protein genetic variants has been carried out through reversed-phase HPLC (RP-HPLC; Bonfatti et al., 2008). Large-scale application of RP-HPLC is not feasible because the technique is time consuming and requires expensive analytical equipment and skilled operators.

Alternative methodologies for measuring MPC rely on the use of mid-infrared (MIR) spectroscopy. Midinfrared spectroscopy is widely used for assessing milk quality and concentration of milk constituents and it has been applied for predicting milk composition (Lynch et al., 2006), milk coagulation properties (De Marchi et al., 2009b), milk fat composition (Soyeurt et al., 2006), and even acetone content for the detection of subclinical ketosis (Heuer et al., 2001). 


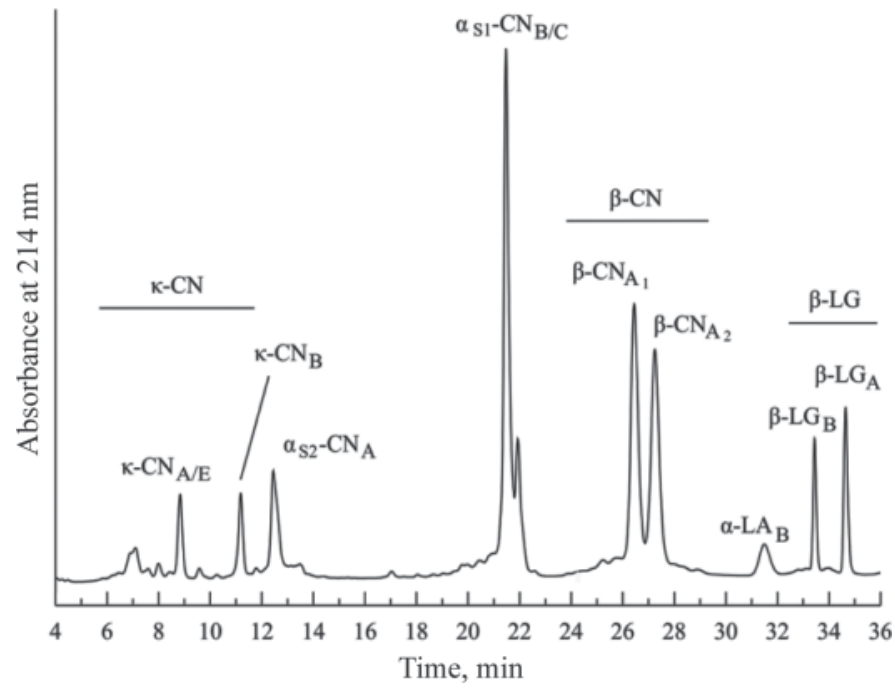

Figure 1. Example of a reversed-phase HPLC chromatogram of an individual milk sample showing all major $\mathrm{CN}$ and whey protein fractions and some of their genetic variants.

Few studies (Díaz-Carrillo et al., 1993; De Marchi et al., 2009a) have investigated the application of infrared spectroscopy for the prediction of MPC. The current study aimed to evaluate the effectiveness of MIR spectroscopy for the prediction of detailed MPC of individual milk samples of Simmental cows.

\section{MATERIALS AND METHODS}

\section{Sample Collection}

Individual milk samples were collected from 1,517 Simmental cows reared in 32 commercial dairy herds located in northern Italy. One milk sample was collected from each cow from March to December 2008 during the morning or evening milking. Parity and DIM at sampling ranged from 1 to 9 and from 5 to 460, respectively. Preservative (Bronopol, 2-bromo2-nitropropan-1,3-diol, 0.6:100 vol/vol; Grunenthal Prodotti \& Farmaceutici Formenti, Milan, Italy) was added to samples, which were frozen immediately after collection using a portable freezer to prevent proteolysis and transferred to the laboratory of the Department of Animal Science (University of Padova, Padova, Italy) for spectra recording and HPLC analysis.

\section{Quantification of Protein Fraction Contents}

Protein fraction contents, as well as contents of the most common protein genetic variants, were quantified by RP-HPLC. For each sample, contents of protein; $\mathrm{CN}$; whey protein; $\alpha_{\mathrm{S}^{-}}, \alpha_{\mathrm{S}_{2}}, \beta-$, and $\kappa-\mathrm{CN} ; \alpha-\mathrm{LA}$ and $\beta-\mathrm{LG}$, were measured simultaneously with no prior $\mathrm{CN}$ precipitation. Because milk protein genetic variants exhibited different absorbances at $214 \mathrm{~nm}$ (Bonfatti et al., 2008) and milk protein commercial standards contain a mixture of genetic variants, each protein genetic variant was extracted and purified by semipreparative RP-HPLC and used for the calibration of the HPLC equipment. A semi-preparative Zorbax 300SB-C8 $(5 \mu \mathrm{m}, 300 \AA, 250 \mathrm{~mm} \times 9.4 \mathrm{~mm}$; Agilent Technologies Inc., Santa Clara, CA) column was used, using the same gradient as that used for the analytical scale separation. The flow rate was set to $2 \mathrm{~mL} / \mathrm{min}$. A specific calibration curve was constructed for each protein genetic variant and $\alpha$-LA, $\beta$-LG A, and $\beta$-LG B were used without further purification. Details on the HPLC technique used in this study, as well as on the repeatability and reproducibility of the method, can be found in Bonfatti et al. (2008). An example of an RPHPLC chromatogram is depicted in Figure 1.

\section{Mid-Infrared Spectra Acquisition}

Samples were thawed in a water bath at $35^{\circ} \mathrm{C}$ before spectra acquisition and absorbance spectra were recorded using a Milko-Scan FT120 [Fourier transform infrared (FTIR) interferometer; Foss Electric A/S, Hillerød, Denmark] over the spectral range from 4,000 to $900 \mathrm{~cm}^{-1}$ within $12 \mathrm{~h}$ after sampling. Two acquisitions were carried out for each sample and averaged before data analysis.

\section{Spectral Transformation and Prediction Models}

Statistical analysis was carried out using partial least square (PLS) and modified PLS (MPLS; Shenk and Westerhaus, 1991) regression procedures as implemented in the software WinISI II (Infrasoft International Inc., State College, PA). Several mathematical treatments of spectra were compared before regression analysis. Spectra were transformed using standard normal variate, detrend, multiplicative scatter correction, and their combinations. Spectra pretreatment involved first- and second-order derivatives. The gaps over which derivatives were calculated ranged from 1 to 20 data points and the smooth ranged from 1 to 8 . Reference data were not transformed before regression analysis.

Samples exhibiting large spectral distance (i.e., with a large Mahalanobis distance) from the population mean and samples for which the difference between the reference and the predicted value was much larger than the standard error of cross-validation $\left(\mathbf{S E C}_{\mathbf{C V}}\right)$ were considered outliers ( $\mathrm{H}$ - and T-outliers, respectively). A T-outlier is a sample exhibiting a relationship between its reference value and its spectra, which differs from the relationship exhibited by the other samples of the 
population, whereas H-outliers are samples that are spectrally different from the other samples of the population (Shenk and Westerhaus, 1995). A T-outlier indicates extreme reference values and it usually implies an error in the regression that could be decreased by improving the accuracy of the reference data. Limits for outlier identification were set to 10 and 3 for $\mathrm{H}$ - and Toutliers, respectively, as suggested by Tillmann (2000). Two steps for outlier elimination were used.

Prediction models were validated using a 4-fold random cross-validation. The $\mathrm{SEC}_{\mathrm{CV}}$ and the coefficient of determination between the predicted and measured values in cross-validation (1-VR) were calculated and used to evaluate the effectiveness of calibration models. The best mathematical treatment of spectra was the one providing the smallest $\mathrm{SEC}_{\mathrm{CV}}$ and the greatest $1-\mathrm{VR}$. The ratio of the range of MPC reference values in prediction to $\mathrm{SEC}_{\mathrm{CV}}$ (range error ratio, RER), as well as the ratio of the standard deviation of MPC reference values in prediction to $\mathrm{SEC}_{\mathrm{CV}}(\mathbf{R P D})$, was also calculated to provide indications about the practical utility of predictive models.

Values of 1-VR ranging from 0.50 to 0.65 indicate poor predictions, with models allowing only for the discrimination between high and low values. Values of 1 -VR between 0.66 and 0.81 indicate fairly accurate predictions, values greater than 0.82 reveal good predictions, and models with 1-VR greater than 0.91 are considered to be excellent (Williams, 2003).

According to Williams (1987), models with RER $<3$ have limited practical utility, whereas models with RER $>10$ have good predictive abilities. According to Sinnaeve et al. (1994) and Karoui et al. (2006), good predictions have an RPD greater than 2 .

\section{RESULTS AND DISCUSSION}

\section{Protein Composition}

Descriptive statistics for MPC of skim milk are reported in Table 1. The high content of total protein $(40.68 \mathrm{~g} / \mathrm{L})$ has to be ascribed to the skimming of milk before chromatographic analysis and to the specific gravity of milk. Indeed, protein content assessed by HPLC was measured in weight per volume. Very large differences for the coefficient of variation across the investigated traits were observed.

\section{Mid-Infrared Spectra}

Prediction models were obtained using spectra in several forms. Omitting the portion of MIR spectra from 3,470 to $3,040 \mathrm{~cm}^{-1}$ and from 1,700 to $1,600 \mathrm{~cm}^{-1}$, as suggested by several researchers (Hewavitharana and van Brakel, 1997; Pillonel et al., 2003; Jørgensen and Næs, 2004) because of a low signal-to-noise ratio due to the absorption by water, did not improve the statistical performance of calibration models. Likely, this occurred because enough samples were available to obtain reliable MPLS loadings for each wavelength.

In general, MPLS regression (Shenk and Westerhaus, 1991) and the use of the first-order derivatives provided the best statistical performance. The first-derivative function was constructed and smoothed over a different number of points to improve the performance of each model. The fraction of T-outliers ranged from 0.7 to $3.4 \%$ of total samples and no H-outliers were observed.

\section{Prediction of Protein Fraction Contents}

Fitting statistics of prediction models for MPC are reported in Table 2. The number of MPLS components for the ultimate prediction model ranged from $2(\gamma-\mathrm{CN})$ to $14(\mathrm{CN}$ number, measured as $\mathrm{CN} /$ protein $\times 100)$. Ideally, a small number of components is preferable if models are to be applied to predict future data.

The very large correlation $(\mathrm{r}>0.98)$ between protein and $\mathrm{CN}$ content made the prediction of $\mathrm{CN}$ unfeasible. When RP-HPLC is used to assess MPC, minor whey proteins and NPN cannot be quantified, resulting in a very high $\mathrm{CN}$ number because of a tight relationship between protein and CN content (Bonfatti et al., 2010b). In addition, CN number showed very limited variability.

The most accurate prediction models were those for total protein, $\mathrm{CN}, \alpha_{\mathrm{S} 1}-\mathrm{CN}, \beta-\mathrm{LG}$, glycosylated $\kappa-\mathrm{CN}$, and total whey protein content that exhibited 1-VR values ranging from 0.61 to 0.78 . Less favorable results were obtained for $\beta-\mathrm{CN}(1-\mathrm{VR}=0.53)$ and $\alpha_{\mathrm{S}^{2}} \mathrm{CN}$ and $\kappa$-CN $(1-\mathrm{VR}=0.49)$. The glycosylated $\kappa$-CN-to-total $\kappa-\mathrm{CN}$ content ratio, which gives indications on the level of $\kappa$-CN glycosylation in milk, exhibited a 1-VR of 0.46. The extent of glycosylation of $\kappa$-CN affects biological properties of C-terminal fragments of $\kappa_{-} \mathrm{CN}$ and micelle stabilization and has been related to technological properties of milk (Dziuba and Minkiewicz, 1996).

Because of very limited amounts in milk, neither the content of $\alpha$-LA nor that of $\gamma$-CN was predicted by MIR spectroscopy with satisfactory accuracy (1-VR of 0.31 and 0.09 for $\alpha$-LA and $\gamma-\mathrm{CN}$, respectively). Unfavorable results were obtained when protein fraction contents were measured as percentage ratios of total protein or CN.

The difficulty of spectra to explain variation of protein fractions, evidenced by the low values of $1-\mathrm{VR}$, was expected because of the nature of the investigated compounds. Protein fractions differ in the length of the AA chain and in the secondary and tertiary structure, 
Table 1. Descriptive statistics for milk protein composition $(1,517 \text { samples })^{1}$

\begin{tabular}{|c|c|c|c|c|}
\hline Item $^{2}$ & Mean & $\mathrm{SD}$ & Minimum & Maximum \\
\hline Protein, g/L & 40.68 & 4.50 & 27.34 & 60.19 \\
\hline $\mathrm{CN}, \mathrm{g} / \mathrm{L}$ & 35.61 & 3.95 & 23.71 & 52.79 \\
\hline Whey protein, $\mathrm{g} / \mathrm{L}$ & 5.06 & 0.71 & 2.66 & 7.40 \\
\hline $\mathrm{CN}$ number, $\%$ & 87.55 & 1.08 & 84.63 & 90.90 \\
\hline \multicolumn{5}{|l|}{$\mathrm{CN}, \mathrm{g} / \mathrm{L}$} \\
\hline$\alpha_{\mathrm{S}^{-}} \mathrm{CN}$ & 12.63 & 1.51 & 6.53 & 19.82 \\
\hline$\alpha_{\mathrm{S}_{2}-} \mathrm{CN}$ & 4.37 & 0.67 & 2.12 & 6.79 \\
\hline$\beta-\mathrm{CN}$ & 13.24 & 1.99 & 5.99 & 20.33 \\
\hline$\gamma-\mathrm{CN}$ & 1.59 & 0.42 & 0.44 & 2.95 \\
\hline$\kappa-\mathrm{CN}$ & 3.70 & 0.88 & 1.29 & 6.84 \\
\hline Glyco-к-CN & 1.76 & 0.59 & 0.58 & 4.43 \\
\hline \multicolumn{5}{|l|}{ Whey protein, g/L } \\
\hline$\alpha-\mathrm{LA}$ & 1.29 & 0.22 & 0.71 & 2.04 \\
\hline$\beta-\mathrm{LG}$ & 3.76 & 0.61 & 1.95 & 5.94 \\
\hline \multicolumn{5}{|c|}{ Protein composition, \% } \\
\hline$\alpha_{\mathrm{S} 1}-\mathrm{CN}$ & 31.12 & 2.22 & 24.89 & 37.87 \\
\hline$\alpha_{\mathrm{S}^{-}} \mathrm{CN}$ & 10.77 & 1.19 & 7.48 & 14.91 \\
\hline$\beta-\mathrm{CN}$ & 32.57 & 2.61 & 24.44 & 40.49 \\
\hline$\gamma-\mathrm{CN}$ & 3.93 & 1.04 & 1.10 & 7.53 \\
\hline$\kappa-\mathrm{CN}$ & 9.10 & 1.81 & 4.11 & 15.55 \\
\hline$\alpha-\mathrm{LA}$ & 3.19 & 0.50 & 1.80 & 4.78 \\
\hline$\beta-\mathrm{LG}$ & 9.24 & 0.97 & 6.29 & 12.30 \\
\hline \multicolumn{5}{|l|}{ CN composition, $\%$} \\
\hline$\alpha_{\mathrm{S1}^{-}} \mathrm{CN}^{1}$ & 35.54 & 2.60 & 28.96 & 43.06 \\
\hline$\alpha_{S_{2}-} \mathrm{CN}$ & 12.31 & 1.39 & 7.92 & 17.52 \\
\hline$\beta-\mathrm{CN}$ & 37.19 & 2.87 & 28.72 & 46.02 \\
\hline$\gamma-\mathrm{CN}$ & 4.49 & 1.19 & 1.24 & 8.62 \\
\hline$\kappa-\mathrm{CN}$ & 10.39 & 2.03 & 4.70 & 17.53 \\
\hline Glyco rate, $\%$ & 47.24 & 7.91 & 24.57 & 81.86 \\
\hline \multicolumn{5}{|c|}{ Whey protein composition, \% } \\
\hline$\beta-\mathrm{LG}$ & 74.24 & 3.76 & 62.54 & 85.56 \\
\hline
\end{tabular}

${ }^{1}$ Proteins were measured on skim milk.

${ }^{2}$ Protein $=\alpha_{\mathrm{S}^{-}} \mathrm{CN}+\alpha_{\mathrm{S}^{-}} \mathrm{CN}+\beta-\mathrm{CN}+\gamma-\mathrm{CN}+\kappa-\mathrm{CN}+\beta-\mathrm{LG}+\alpha-\mathrm{LA} ; \mathrm{CN}=\alpha_{\mathrm{S}^{-}} \mathrm{CN}+\alpha_{\mathrm{S}^{-}} \mathrm{CN}+\beta-\mathrm{CN}+$ $\gamma-\mathrm{CN}+\kappa-\mathrm{CN}$; whey protein $=\beta-\mathrm{LG}+\alpha-\mathrm{LA} ; \mathrm{CN}$ number $=(\mathrm{CN} /$ protein $) \times 100 ;$ glyco rate $=$ percentage of glycosylated $\kappa-\mathrm{CN}$ in total $\kappa-\mathrm{CN}$.

rather than in the kind of chemical bonds. In addition, the heterogeneity within each protein fraction (presence of glycosylated and phosphorylated forms) makes the prediction based on the use of spectra difficult.

Also, the relatively poor prediction of total protein content was in part expected, with total protein being the sum of the major, but not all, protein fractions. For example, BSA, immunoglobulins, proteose-peptones, and other minor serum proteins and peptides or single AA were not taken into account. Moreover, protein was measured on skim milk and expressed in weight per volume instead of in weight per weight. As a consequence, the volume of fat could affect protein concentration and, together with the specific gravity of milk, contributed in making total protein measured by RP-HPLC different from that obtained with the Kjeldahl method, which also includes NPN. For all of these reasons, comparing the prediction of total protein content measured by RP-HPLC with that used for milk payment, which is based on the total amount of nitrogen in milk, is not appropriate.
Results of this study are partially consistent with those reported by De Marchi et al. (2009a) in a preliminary study aimed to investigate the feasibility of predicting major milk protein fractions contents using MIR spectroscopy. In that study, MIR spectroscopy performed worse for the prediction of all the investigated traits, but prediction models were obtained by using PLS and untreated spectra in the combined ranges from 4,000 to $3,460 \mathrm{~cm}^{-1}$, from 3,040 to $1,701 \mathrm{~cm}^{-1}$, and from 1,604 to $1,000 \mathrm{~cm}^{-1}$. Using near-infrared spectroscopy, Díaz-Carrillo et al. (1993) obtained models exhibiting 1-VR ranging from 0.86 to 0.92 for protein composition of goat milk. They preprocessed samples using adsorption of milk on glass fiber filters and drying for $4 \mathrm{~h}$ before spectra acquisition. In contrast with our results, 1-VR obtained by Díaz-Carrillo et al. (1993) for $\kappa-C N$ content was similar to those obtained for the other main protein fractions. Likely, these inconsistencies are to be ascribed to the greater content of $\kappa-\mathrm{CN}$ in goat milk relative to that of cow milk (Fox and McSweeney, 2003). Moreover, in our study, milk was frozen and 
Table 2. Fitting statistics of predictions models for milk protein composition

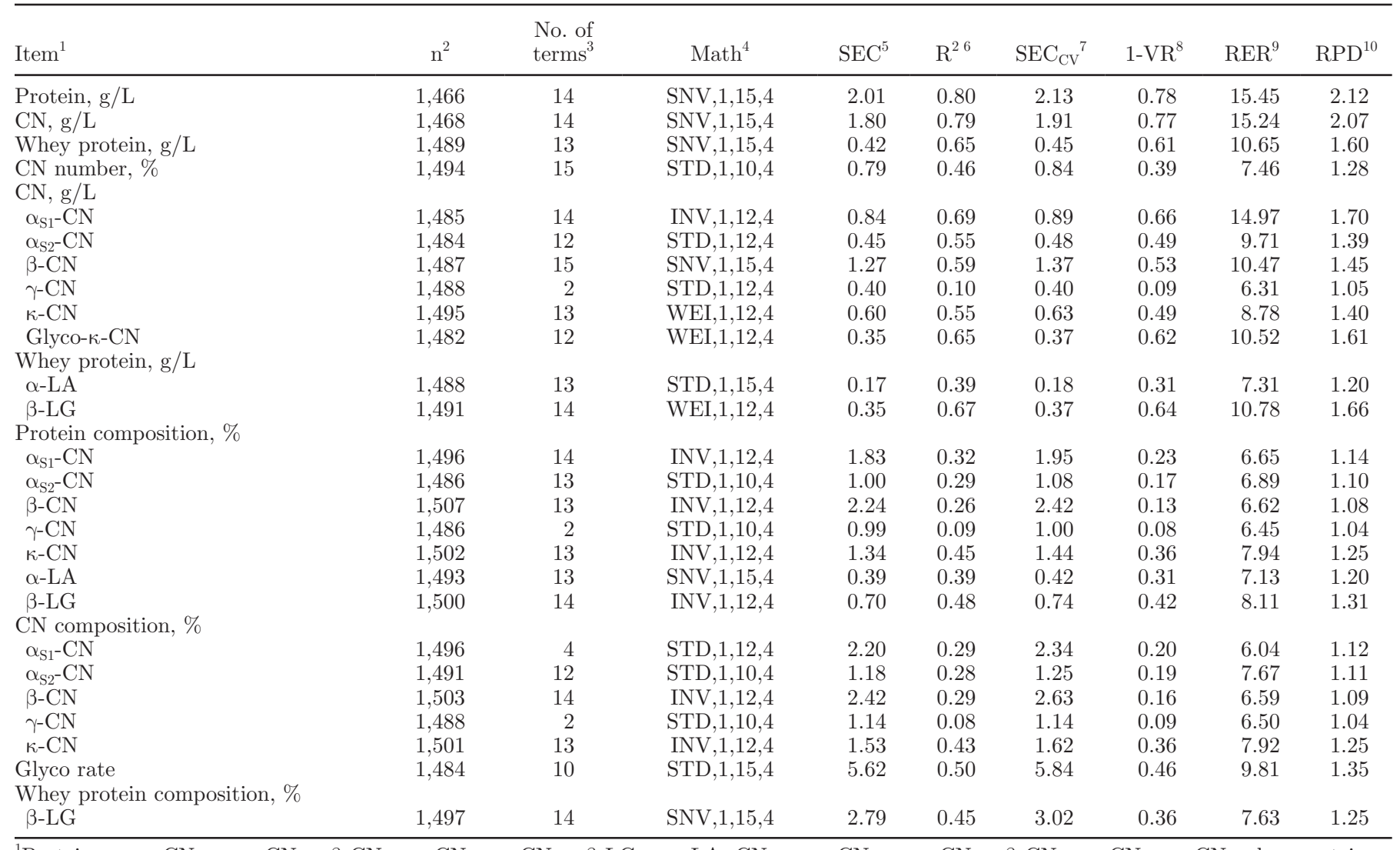

${ }^{1}$ Protein $=\alpha_{\mathrm{S}^{-}} \mathrm{CN}+\alpha_{\mathrm{S} 2}-\mathrm{CN}+\beta-\mathrm{CN}+\gamma-\mathrm{CN}+\kappa-\mathrm{CN}+\beta-\mathrm{LG}+\alpha-\mathrm{LA} ; \mathrm{CN}=\alpha_{\mathrm{S}_{1}} \mathrm{CN}+\alpha_{\mathrm{S} 2}-\mathrm{CN}+\beta-\mathrm{CN}+\gamma-\mathrm{CN}+\kappa-\mathrm{CN} ;$ whey protein $=$ $\beta-\mathrm{LG}+\alpha-\mathrm{LA} ; \mathrm{CN}$ number $=(\mathrm{CN} /$ protein $) \times 100 ;$ glyco rate $=$ percentage of glycosylated $\kappa-\mathrm{CN}$ in total $\kappa-\mathrm{CN}$.

${ }^{2} \mathrm{n}=$ number of samples used in the calibration after removing outliers.

${ }^{3}$ No. of terms $=$ number of modified partial least square components.

${ }^{4} \mathrm{Math}=$ mathematical treatments of the spectral data where the 3 letters indicate standard normal variate and detrend (SNV), standard multiplicative scatter correction (STD), weighted multiplicative scatter correction (WEI), or inverse multiplicative scatter correction (INV), the first number is the order of the derivative, the second number is the segment length in data points over which the derivative was taken, and the third number is the segment length over which the function was smoothed.

${ }^{5} \mathrm{SEC}=$ standard error of calibration.

${ }^{6} \mathrm{R}^{2}=$ coefficient of determination of calibration.

${ }^{7} \mathrm{SEC}_{\mathrm{CV}}=$ standard error of cross-validation.

${ }^{8} 1$-VR $=$ coefficient of determination of cross-validation.

${ }^{9} \mathrm{RER}=\mathrm{SEC}_{\mathrm{CV}} /$ range.

${ }^{10} \mathrm{RPD}=\mathrm{SEC}_{\mathrm{CV}} / \mathrm{SD}$.

then thawed before spectra acquisition and physical changes in $\mathrm{CN}$ micelles due to low temperature might have interfered with MIR spectroscopy prediction of protein fraction contents. Milk fat might have affected the predictive ability of MIR spectroscopy because reference protein composition was measured on skim milk, whereas spectra acquisition was performed on raw milk. Although 1-VR values were moderate, RER for predictions of total protein (15.45), CN (15.24), $\alpha_{\mathrm{S}_{1}-} \mathrm{CN}$ (14.97), $\beta$-LG (10.78), whey protein (10.65), glycosylated $\kappa-\mathrm{CN}(10.52)$, and $\beta$-CN (10.45) contents indicate a high practical utility of models (Williams, 1987). Being sensitive to extreme values, RER is less effective than RPD as an indicator of usefulness of calibration models. Values of RPD greater than 1.5 were obtained for all of the aforementioned traits, with the only exception of $\beta-\mathrm{CN}$, but values of RPD greater than 2 were obtained only for protein and CN content.

The best predictions were obtained for total protein or for fractions that are present in milk in large amounts. Despite a large relative content in $\mathrm{CN}, \beta-\mathrm{CN}$ showed a value of $1-\mathrm{VR}$ that was moderate and similar to that obtained for $\kappa$-CN. This can be explained by the multimodal frequency distribution of $\beta-\mathrm{CN}$ and $\kappa-\mathrm{CN}$ content (Figure 2) due to CSN2 and CSN3 genotype effects. For $\beta$-CN and $\kappa-\mathrm{CN}$, homozygous B 
animals exhibit greater contents of the protein fraction relative to heterozygous animals or homozygous individuals carrying alternative alleles. For this reason, contents of these 2 protein fractions are expected to be poorly modeled by linear regressions. When calibration equations were estimated using $\beta-\mathrm{CN}$ and $\kappa-\mathrm{CN}$ contents adjusted for $C S N 2$ and $C S N 3$ genotype effects in place of unadjusted contents, the accuracy of calibration equations increased. For adjusted contents, 1-VR was 0.74 and 0.61 for $\beta-\mathrm{CN}$ and $\kappa-\mathrm{CN}$, respectively. Moreover, adjustment of fraction contents for genotype effects enhanced the practical utility of models: RER and RPD were 16.03 and 2.10 for the adjusted content of $\beta-\mathrm{CN}$ and 12.69 and 1.72 for the content of $\kappa-\mathrm{CN}$, respectively.

To investigate the molecular basis of MPC prediction, the loadings of the first and of the second MPLS component were examined. The loadings of the first and second MPLS component for main CN fractions and $\beta-\mathrm{LG}$ are depicted in Figure 3. Examination of loadings detected that spectral regions of relevance were the ones that have been reported (Hewavitharana and van Brakel, 1997) to correlate with milk protein content. Peaks showed similar variation and overlapped for most protein fractions. This was expected because of the nature of the investigated compounds. Protein
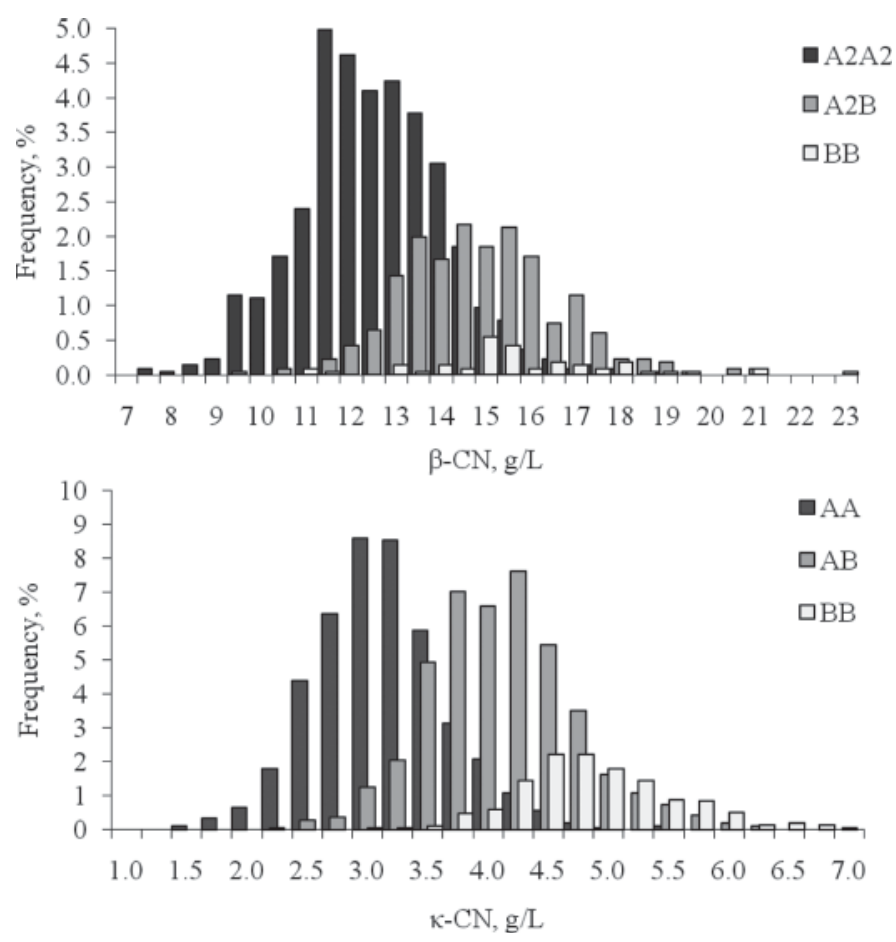

Figure 2. Frequency distribution of $\beta-\mathrm{CN}$ content in milk of cows of different CSN2 genotype (A2A2, A2B, or BB) and of $\kappa-C N$ content in milk of cows of different CSN3 genotype (AA, $\mathrm{AB}$, or $\mathrm{BB})$. fractions do not differ in the nature of chemical bonds. In addition, presence of alternative genetic variants and phosphorylated forms within each protein fraction unfavorably affects the role of spectra in the prediction of MPC.

Being proteins, all $\mathrm{CN}$ and whey protein fractions were expected to show peaks around 1,650, and 1,550 $\mathrm{cm}^{-1}$ due to amide I and amide II bands, respectively. Moreover, peaks between 1,300 and $1,000 \mathrm{~cm}^{-1}$ due to ionic and covalent phosphate bonds were expected. Sulfur AA were responsible for the S-H stretch vibration occurring between 2,500 and $2,600 \mathrm{~cm}^{-1}$. Other vibrations, such as S-S and C-S, were observed below $1,000 \mathrm{~cm}^{-1}$. A good correlation was observed also between 2,800 and $3,600 \mathrm{~cm}^{-1}$ due to $\mathrm{C}-\mathrm{H}$ and $\mathrm{O}-\mathrm{H}$ stretching. Loadings were almost identical for protein, $\mathrm{CN}$, and whey protein (data not reported). Loadings for $\beta-\mathrm{LG}, \beta-\mathrm{CN}$, and $\kappa-\mathrm{CN}$ were very similar, as well as were those for $\alpha_{\mathrm{S}_{1}}-\mathrm{CN}$ and $\alpha_{\mathrm{S}_{2}} \mathrm{CN}$, particularly in the fingerprint region (below $1,400 \mathrm{~cm}^{-1}$ ). Due to the presence of carbohydrates, glycosylated $\kappa-\mathrm{CN}$ showed a substantial variation of loadings relative to those of the other fractions.

\section{Prediction of Protein Genetic Variant Contents}

Because of known relationships with technological properties of milk (Bonfatti et al., 2010ab), predicting the content of specific genetic variants within a protein fraction might be of interest. Calibration models for predicting the content of the most common protein genetic variants $\left(\kappa-\mathrm{CN} \mathrm{A}\right.$ and $\mathrm{B} ; \beta-\mathrm{CN} \mathrm{A}^{1}, \mathrm{~A}^{2}$, and $\mathrm{B}$; and $\beta$-LG $\mathrm{A}$ and $\mathrm{B}$ ) were estimated, across and within genotypes, but the accuracy of all of these models was unsatisfactory (data not reported in tables). Predicting the content of $\kappa-\mathrm{CN}$ genetic variants with acceptable accuracy was unfeasible $(1-\mathrm{VR}<0.15)$ and the prediction for $\beta-\mathrm{CN}$ variants was very inaccurate $(1-\mathrm{VR}<0.01)$. The best predictions were achieved for $\beta-\mathrm{LG} \mathrm{A}$ and $\beta$-LG B contents (1-VR of 0.60 and 0.44 , respectively). These results indicate that MIR spectroscopy is not able to assess contents of milk protein genetic variants. In a recent study, Berget et al. (2010) were able to classify CSN1S1 goat genotypes through MIR technology with good accuracy. The content of $\alpha_{\mathrm{S}_{1}} \mathrm{CN}$ in goat milk is markedly affected by genotypes at CSN1S1 because null alleles are present, causing no expression of the gene and responsible for very low $\alpha_{S 1}-\mathrm{CN}$ content in milk. Conversely, cows carrying different haplotypes at milk protein genes show smaller differences in protein composition relative to goats. This makes the identification of $C S N 2, C S N 3$, and $B L G$ genotypes on the basis of the predicted content of protein variants unfeasible for bovine milk. 

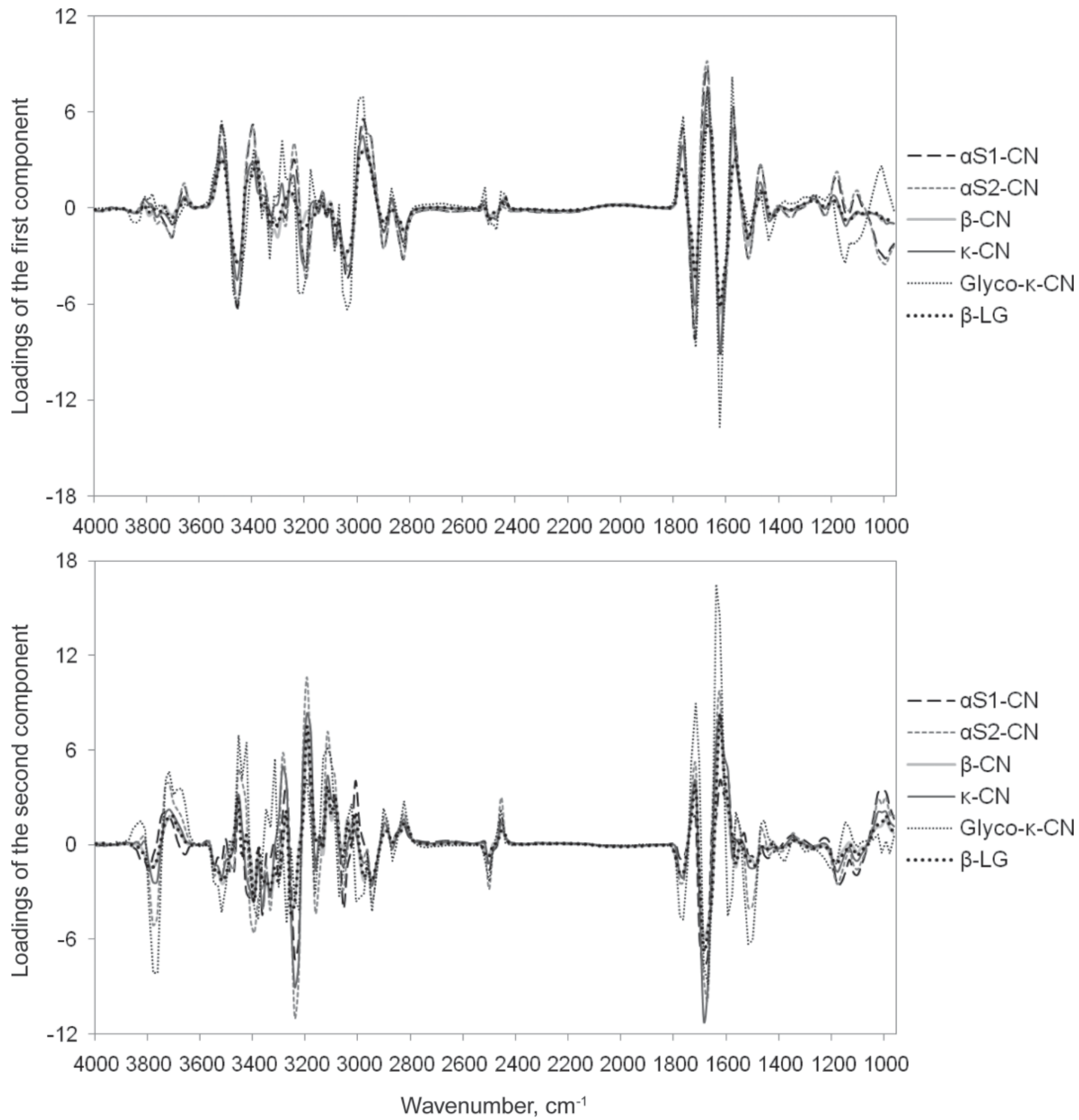

Figure 3. Loadings of the first and second modified partial least squares regression component for CN fractions and $\beta$-LG.

\section{Practical Utility of the Prediction Models}

Results of this study indicate that MIR spectroscopy has the potential to predict the total protein and CN content of milk, as well as the content of total whey protein, $\alpha_{\mathrm{S}_{1}} \mathrm{CN}, \beta-\mathrm{LG}$, and glyco- $\kappa-\mathrm{CN}$, but with mod- erate accuracy. Scatter plots of predicted versus measured protein fractions contents are depicted in Figure 4. Calibration models obtained in this study were effective only to discriminate between samples showing high and low content of $\beta-\mathrm{CN}, \alpha_{\mathrm{S}^{2}} \mathrm{CN}$, and $\kappa-\mathrm{CN}$. Use of near infrared spectroscopy analysis of dried samples 

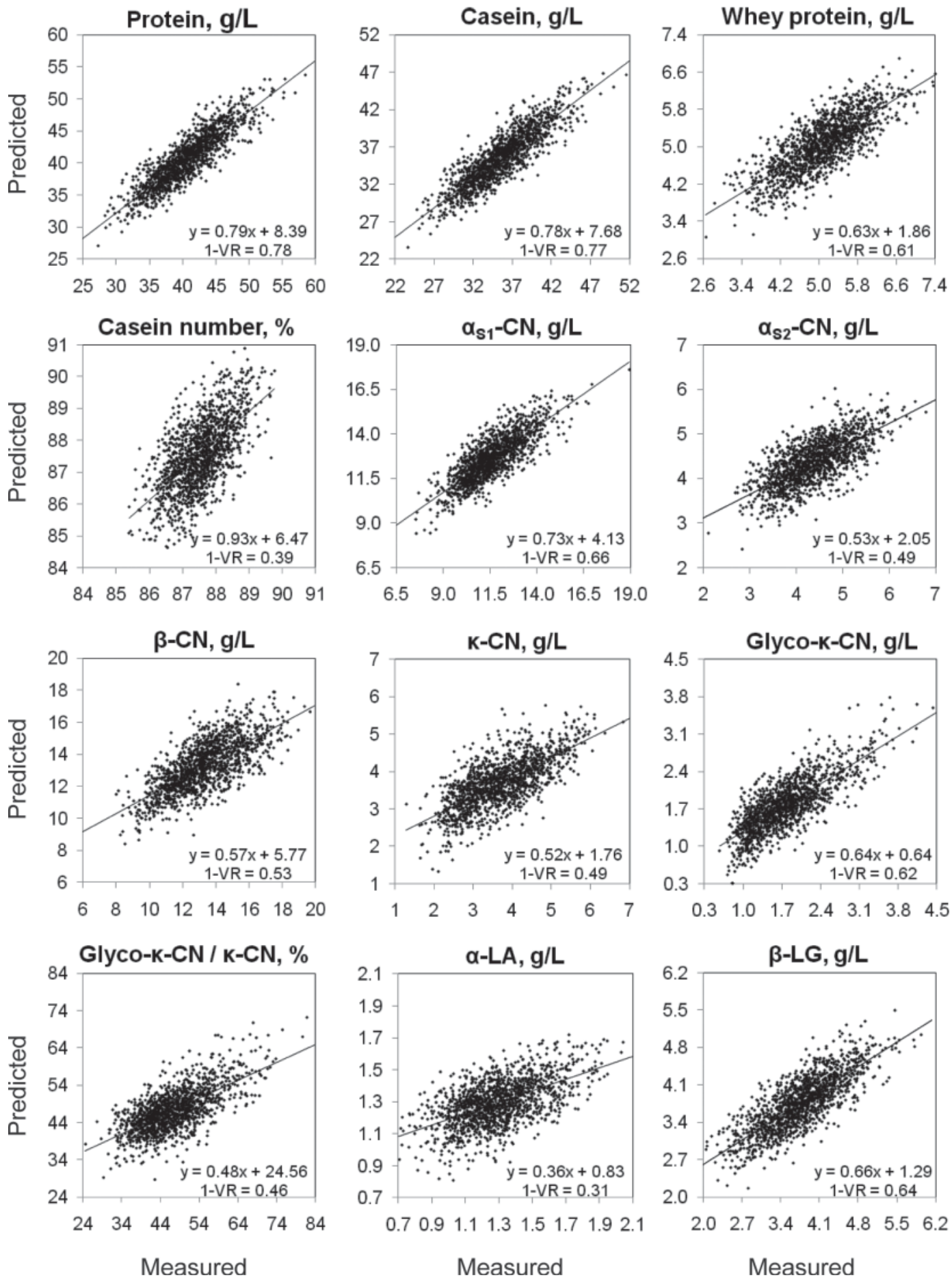

Figure 4. Scatter plots of predicted (y-axis) on measured (x-axis) milk protein fraction contents, regression equation, and coefficient of determination of cross-validation (1-VR).

has been suggested as an alternative to increase the accuracy of predictions (Díaz-Carrillo et al., 1993). However, Fourier transform infrared (FTIR) spectrometers (Milkoscan FT 6000; Foss Electric A/S) are still a very attractive option for routine assessment of quality of raw milk, due to the opportunity of prompt and inexpensive upgrading of the equipment with additional prediction equations for new traits.

Values of RPD $>2$ and RER $>10$ are considered to indicate successful calibrations, but calibrations with 
lower predictive ability may still be useful, depending on the use of predictions. As an example, MIR spectroscopy predictions may play a role as indicator traits of MPC in selective breeding. When altering MPC through selective breeding is of interest, the usefulness of MIR spectroscopy predictions of MPC heavily relies on the genetic variation of the predictions and on the magnitude of the genetic correlations between predicted and measured MPC. Cecchinato et al. (2009) reported that the correlated response of milk coagulation properties due to selective breeding based on MIR spectroscopy predictions as indicator traits, for which accuracy is similar to that of MPC predictions, was expected to be equal to or slightly lower than the response achievable through direct measurement of milk coagulation properties. Hence, if the genetic correlation between measured and MIR spectroscopy-predicted contents of milk protein fractions is large enough and acquisition of spectra from individual milk samples is routinely performed for a dairy cattle population, strategies to enhance MPC through selective breeding can be promptly and easily implemented.

\section{CONCLUSIONS}

The potential of MIR spectroscopy to predict protein composition was investigated using individual milk samples. Results of this study indicate that MIR spectroscopy is not applicable for predicting detailed milk protein composition when high accuracy is critical, as is the case for the milk payment system. Accuracy of predictions based on near-infrared spectroscopy and acquisition of spectra from dried milk samples, as alternatives to MIR spectroscopy predictions, needs to be investigated. The practical utility of MIR spectroscopy predictions of MPC for selective breeding purposes depends upon the genetic correlation between the predicted and measured values. When this correlation and the genetic variance of the predictions are large enough, even predictions exhibiting fair accuracy are of practical value. The estimated prediction models can be used to provide breeding organizations with information on indicator traits for milk protein composition and the opportunity of enhancing protein composition through indirect selection. Estimates of genetic parameters for MIR spectroscopy-predicted MPC are needed to assess the efficiency of indirect selection for MPC based on MIR spectroscopy predictions.

\section{ACKNOWLEDGMENTS}

The authors thank the Italian Simmental Cattle Breeder Association (ANAPRI) and the Milk Recording Agency of Friuli Venezia Giulia (AAFVG) for the organization of milk sampling. Financial support by Regione del Veneto (Azione Biotech III Bis, Delibera CIPE n. 03, 22/03/2006) is also gratefully acknowledged.

\section{REFERENCES}

Berget, I., H. Martens, A. Kohler, S. K. Sjurseth, N. K. Afseth, B. Narum, T. Ådnøy, and S. Lien. 2010. Caprine CSN1S1 haplotype effect on gene expression and milk composition measured by Fourier transform infrared spectroscopy. J. Dairy Sci. 93:4340-4350.

Bonfatti, V., A. Cecchinato, G. Di Martino, M. De Marchi, L. Gallo, and P. Carnier. 2011. Effect of $\kappa$-casein B relative content in bulk milk $\kappa$-casein on Montasio, Asiago, and Caciotta cheese yield using milk of similar protein composition. J. Dairy Sci. 94:602-613.

Bonfatti, V., G. Di Martino, A. Cecchinato, L. Degano, and P. Carnier. 2010a. Effects of $\beta$-к-casein (CSN2-CSN3) haplotypes, $\beta$-lactoglobulin $(B L G)$ genotypes, and detailed protein composition on coagulation properties of individual milk of Simmental cows. J. Dairy Sci. 93:3809-3817.

Bonfatti, V., G. Di Martino, A. Cecchinato, D. Vicario, and P. Carnier. 2010b. Effects of $\beta$-к-casein (CSN2-CSN3) haplotypes and $\beta$-lactoglobulin $(B L G)$ genotypes on milk production traits and detailed protein composition of individual milk of Simmental cows. J. Dairy Sci. 93:3797-3808.

Bonfatti, V., L. Grigoletto, A. Cecchinato, L. Gallo, and P. Carnier. 2008. Validation of a new reversed-phase high-performance liquid chromatography method for separation and identification of bovine milk protein genetic variants. J. Chromatogr. A 1195:101-106.

Cecchinato, A., M. De Marchi, L. Gallo, G. Bittante, and P. Carnier. 2009. Mid-infrared spectroscopy predictions as indicator traits in breeding programs for enhanced coagulation properties of milk. J. Dairy Sci. 92:5304-5313.

De Marchi, M., V. Bonfatti, A. Cecchinato, G. Di Martino, and P. Carnier. 2009a. Prediction of protein composition of individual cow milk using mid-infrared spectroscopy. Ital. J. Anim. Sci. 8(Suppl. 2):399-401.

De Marchi, M., C. C. Fagan, C. P. O'Donnell, A. Cecchinato, R. Dal Zotto, M. Cassandro, M. Penasa, and G. Bittante. 2009b. Prediction of coagulation properties, titratable acidity, and $\mathrm{pH}$ of bovine milk using mid-infrared spectroscopy. J. Dairy Sci. 92:423-432.

Díaz-Carrillo, E., A. Muñoz-Serrano, A. Alonso-Moraga, and J. M. Serradilla-Manrique. 1993. Near infrared calibrations for goat's milk components: Protein, total casein, $\alpha_{s^{-}}, \beta-$ and $\kappa$-caseins, fat and lactose. J. Near Infrared Spectrosc. 1:141-146.

Dziuba, J., and P. Minkiewicz. 1996. Influence of glycosylation on micelle-stabilizing ability and biological properties of C-terminal fragments of cow's K-casein. Int. Dairy J. 6:1017-1044.

Fox, P. F., and P. L. H. McSweeney. 2003. Advanced Dairy Chemistry: Volume 1: Proteins, Part A. 3rd ed. Kluwer Academic/Plenum Publishers, New York, NY.

Heck, J. M. L., C. Olieman, A. Schennink, H. J. F. van Valenberg, M. H. P. W. Visker, R. C. R. Meuldijk, and A. C. M. van Hooijdonk. 2008. Estimation of variation in concentration, phosphorylation and genetic polymorphism of milk proteins using capillary zone electrophoresis. Int. Dairy J. 18:548-555.

Heck, J. M. L., A. Schennink, H. J. F. van Valenberg, H. Bovenhuis, M. H. P. W. Visker, J. A. M. van Arendonk, and A. C. M. van Hooijdonk. 2009. Effects of milk protein variants on the protein composition of bovine milk. J. Dairy Sci. 92:1192-1202.

Heuer, C., H. J. Luinge, E. T. G. Lutz, Y. H. Schukken, J. H. van der Maas, H. Wilmink, and J. P. T. M. Noordhuizen. 2001. Determination of acetone in cow milk by Fourier transform infrared spectroscopy for the detection of subclinical ketosis. J. Dairy Sci. 84:575-582.

Hewavitharana, A. K., and B. van Brakel. 1997. Fourier transform infrared spectrometric method for rapid determination of casein in raw milk. Analyst (Lond.) 122:701-704.

Jørgensen, K., and T. Næs. 2004. A design and analysis strategy for situations with uncontrolled raw material variation. J. Chemometrics $18: 45-52$. 
Jõudu, I., M. Henno, T. Kaart, T. Püssa, and O. Kärt. 2008. The effect of milk protein contents on the rennet coagulation properties of milk from individual dairy cows. Int. Dairy J. 18:964-967.

Karoui, R., A. M. Mouazen, É. Dufour, L. Pillonel, D. Picque, J. De Baerdemaeker, and J.-O. Bosset. 2006. Application of the MIR for the determination of some chemical parameters in European Emmental cheeses produced during summer. Eur. Food Res. Technol. 222:165-170.

Lynch, J. M., D. M. Barbano, M. Schweisthal, and J. R. Fleming. 2006. Precalibration evaluation procedures for mid-infrared milk analyzers. J. Dairy Sci. 89:2761-2774.

Pillonel, L., W. Luginbühl, D. Pique, E. Schaller, R. Tabacchi, and J. O. Bosset. 2003. Analytical methods for the determination of the geographic origin of Emmental cheese: Mid- and near-infrared spectroscopy. Eur. Food Res. Technol. 216:174-178.

Schopen, G. C. B., J. M. L. Heck, H. Bovenhuis, M. H. P. Visker, H. J. F. van Valenberg, and J. A. M. van Arendonk. 2009. Genetic parameters for major milk proteins in Dutch Holstein-Friesians. J. Dairy Sci. 92:1182-1191.

Shenk, J. S., and M. O. Westerhaus. 1991. Population definition, sample selection, and calibration procedures for near infrared reflectance spectroscopy. Crop Sci. 31:469-474.

Shenk, J. S., and M. O. Westerhaus. 1995. Forage analysis by near infrared spectroscopy. Pages 111-120 in Forages. Vol. II. The Science of Grassland Agriculture. 5th ed. R. F. Barnes, D. A. Miller, and C. J. Nelson, ed., Iowa State University Press, Ames, IA.

Sinnaeve, G., P. Dardenne, R. Agneessens, and R. Biston. 1994. The use of near infrared spectroscopy for the analysis of fresh grass silage. J. Near Infrared Spectrosc. 2:79-84.

Soyeurt, H., P. Dardenne, F. Dehareng, G. Lognay, D. Veselko, M. Marlier, C. Bertozzi, P. Mayeres, and N. Gengler. 2006. Estimating fatty acid content in cow milk using mid-infrared spectrometry. J. Dairy Sci. 89:3690-3695.

Tillmann, P. 2000. Kalibrationsentwicklung für NIRS-Geräte. Cuvillier Verlag, Göttingen, Germany.

Wedholm, A., L. B. Larsen, H. Lindmark-Månsson, A. H. Karlsson, and A. Andrén. 2006. Effect of protein composition on the cheesemaking properties of milk from individual dairy cows. J. Dairy Sci. 89:3296-3305.

Williams, P. C. 1987. Implementation of near-infrared technology Pages 143-167 in Near-Infrared Technology in the Agricultural and Food Industries. 2nd ed. P. C. Williams, and K. Norris, ed. American Association of Cereal Chemists, St. Paul, MN.

Williams, P. C. 2003. Near-infrared technology getting the best out of light. Page 109 in A Short Course in the Practical Implementation of Near Infrared Spectroscopy for the User. 1.1 ed. PDK Projects Inc., Nanaimo, BC, Canada. 